\title{
The Review of Regulations Through Ministry of Law and Human Rights
}

\author{
Tundjung Herning Sitabuana ${ }^{1 *}$ Ahmad Redi $^{1}$ Shella Felicia ${ }^{1}$
}

\author{
${ }^{I}$ Faculty of Law Universitas Tarumanagara, West Jakarta, Indonesia \\ *Corresponding author. Email: tundjunghidayat@yahoo.com
}

\begin{abstract}
Indonesia has identified itself as the state of law (rechtsstaat). The principle of the rule of law undoubtedly underlies the life of the state and nation by embodying hierarchical legal norms culminating in constitution. However, the inconsistency between the laws and regulations is inevitable in constitutional practice thus the Supreme Court and Constitutional Court are ruled to examine legal products from the legislative and executive institutions under the mandate of the Act of 1945. Nevertheless, in the progress, Ministry of Law and Human Rights issued a policy that norm disputes under the Laws can be reviewed judicially through mediation by the Ministry. Therefore, this study aims to analyze the legality and fulfillment of the value of justice in the practice of norm dispute resolution through mediation. This study uses normative research method and is based on the theory of hierarchical relation of legal norms and the theory of concept of law. The result of the study is in spite of the effectiveness, mediation as an alternative resolution of norm disputes contradicts with the higher legislations that the regulation needs to be readjusted.
\end{abstract}

Key Words: Review of Regulations, Mediation, Ministry of Law and Human Rights

\section{INTRODUCTION}

The supremacy of law is a logical consequence from the existence of Indonesia as a legal state. Therefore, various legal norms are formed as guidelines in the relation between citizens, between citizens and the state, and between state institutions. To begin with, the understanding that Republic of Indonesia was concepted after rule of law was implicitly contained in a series of provisions of the Constitution of the Republic of Indonesia of 1945 before amendments, or known as UUD 1945 by the local people. [1] The formulation of rule of law is implied in the Annotations of 1945 Constitution regarding the Government System which reads "... As Indonesian State is based on law (rechtstaat), it is not founded on power alone (macthstaat) ...". After amended, the concept of rule of law is written explicitly and directly in Article 1 paragraph (3) of UUD 1945 that the Indonesia is a state based on the rule of law.

The perspective of Indonesian rule of law is different from the concept of rule of law adopted by Anglo Saxon and Continental Legal System. Indonesia as a rechtstaat was build on Pancasila as the state fundamental norm that born and developed from the perspective of life and historical background of the nation. The role of the state largely involved for the greater happiness of its people, as written in paragraph IV of UUD 1945. Thus, Indonesia is a welfare state based on law. [2] Stahl describes four elements of rechtstaat which include the existence of human rights protection, separation or division of power, government based on rules-regulations (wetmatigheid van bestuur), and a free trial. In its development, the state must carry out a duty in performing the public interests coinciding with the concept of welfare state (verzorgingstaat). [3] In accordance with legality principle as the result of legal state, the value of Pancasila is further formulated in regulations which is now hierarchically formed in Article 7 of Law No. 12 of 2011 concerning the Establishment of Legislation (Law 12/2011), including:

a. UUD NRI Tahun 1945;

b. Ketetapan Majelis Permusyawaratan Rakyat;

c. UU/Peraturan Pemerintah Pengganti UndangUndang;

d. Peraturan Pemerintah (PP);

e. Peraturan Presiden (Perpres);

f. Peraturan Daerah (Perda) Provinsi;

g. Perda Kabupaten/Kota.

Based on the provisions of Article 8 paragraph (1) of Law $12 / 2011$, in addition to the above laws and regulations, the regulations issued by the People's Consultative Assembly, the House of Representatives, the Regional Representative Council, the Supreme Court, the Constitutional Court, the Financial Audit Board, the Judicial Commission, Bank Indonesia, Ministers, agencies, institutions or commissions established by the Act or Government at the behest of the Law, Provincial Regional Representatives, Governors, City/Municipality Regional Representatives, Chief of City/Municipality, Village Heads or the same level includes the types of legislation.

Legal studies on the hierarchy of legislation are closely related to the Theory of Structures (Stufenbau Theorie) developed by Hans Kelsen and Hans Nawiasky. Regarding law as a scientific discipline, Hans Kelsen revealed that the validity of a law lies in its conformity with other norms, 
especially the highest norms of grund norms. [4] Law as a unity is a series of hierarchical relationships between norms with one another that must not be contradictory. However, there are often inconsistencies between laws and regulations in practice, both similar and different levels. Therefore, there are restrictions that limit the interests and rights of all parties in order to avoid the arbitrariness of policy-making institutions. [5] In case of a regulation deemed contrary to a higher legislation, the provisions involved will be reviewed by the judiciary power in order to ensure the validity of the regulation. It is judicial review. [6]

During post-reformation that concluded by the shift of the supremacy of the People's Consultative Assembly of the Republic of Indonesia (MPR) to constitutional supremacy, fundamental changes occured which impacted in an institutional and constitutional mechanism of judicial review. The Institute of Justice was established to address the possibility of disputes between policy-making state institutions that had denoted the equality, yet the implementation of checks and balances between each power. [7] Since regulations mostly used as grounds are produced by the executive and legislative institutions, the Supreme Court (MA) and the Constitutional Court (MK) are formed in a strategic position to carry out normative control towards each regulation in order to correspond vertically with 1945 Constitution and the Act. [8]

Indonesia adheres to three models of judicial review, namely the judicial review against the Constitution by the Constitutional Court, review of legislation under the law against the Act by the Supreme Court, and review of decree or actions of administrative bodies or officials state by the State Administrative Court. [9] Meanwhile in the progress of time, Ministry of Law and Human Rights (Kemenkumham) ruled out Ministry of Law and Human Rights Regulation Number 32 Year 2017 (Permenkumham 32/2017) concerning Procedures for Legislation Disputes Settlement through Non-Litigation or translated as Tata Cara Penyelesaian Sengketa Peraturan Perundang-undangan melalui Jalur Nonlitigasi which has been amended by Permenkumham No. 2 of 2019 concerning the Settlement of Laws and Regulations Disharmonies through Mediation (Permenkumham 2/2019) or known as Permenkumham Penyelesaian Disharmoni Peraturan Perundang-undangan. Kemenkumham develops alternative resolution for resolving conflict of laws regulations under the Act. According to Article 1 paragraph (1) of the Supreme Court Regulation (PERMA) No. 1 of 2016 concerning Mediation Procedure in Courts, mediation is a method of resolving disputes through the negotiation process to obtain an agreement of the Parties assisted by the Mediator. Specifically, the Ministry of Law and Human Rights regulates in Article 1 paragraph (3) Permenkumham 2/2019 that mediation is an attempt to resolve disharmony in legislation by non-litigation carried out by the Director General of Legislation (Dirjen PP) Ministry of Law and Human Rights. This refinement resulted in another inconsistency of the state institutions' functions as judicial review has continuously been the domain of judicial power through the mechanism of litigation. The Government's efforts in structuring this regulation violate the provisions of the Constitution and other related laws and regulations. Nonetheless, the mediation of norm disputes effectively reached an agreement to resolve the discord of regulations in theBased on the elaborations above, the author is interested in writing the development of this research with title "THE REVIEW OF REGULATIONS THROUGH MINISTRY OF LAW AND HUMAN RIGHTS".

\section{ANALYSIS}

Reviewing legislation or often known as toetsing (legal review) is an authority to assess whether a statutory regulation is compliant or contrary to a higher degree of regulation, and whether a certain authority has the right to issue a certain regulation. [10] The reviews carried out are normative, namely the reviews of general-abstract norms or principles in regulations, out of certain material or physical actions. Norm is a measure or standard or guideline for one's deed or behavior in society. [11] General-abstract norms mean the norms aimed at public and the substances ruled are not determined specifically. [12] Regulation review is distinguished by judicial review, legislative review, and executive review. [13] Judicial review is externally carried out by institutions outside the regulatory body, both regulations made by the legislature and the executive through court proceedings. On the other hand, legislative review and executive review are internal reviews performed on regulations formulated by the regulatory institutions themselves. Legislative review is conducted by changes, reimbursement, revocation, or review of the relevant regulations by the legislative body while the executive review is held following the objections (doleansi) and administrative appeal (administrative beoref). [14]

In 2017, the Ministry of Law and Human Rights published a breakthrough by promulgating Permenkumham 32/2017 amended by Permenkuham 2/2019 regarding the review of legislation under the Law through mediation held by the Directorate General of Legislation. The scope of dispute norms included as the object of the Permenkumham is the contradiction of laws and regulations both vertically and horizontally which cause conflicts of legal norms and authorities between ministries or institutions and local governments causing injustice to the people and business actors and hamper the investment climate, business, and both national and regional economic activities. These inconsistent norms can be applied for dispute resolution through nonlitigation, as ruled in the provisions of Article 2 paragraph (1) Permenkumham 32/2017. In this case, people, including individuals, groups, government agencies, and legal entities, are able to request for review of legislation that is considered to cause disharmony or contradiction with other laws and regulations. [15] Article 2 of Permenkumham No. 2/2019 limits legislation that can be applied for examination by the Ministry of Law and Human Rights including Ministerial Regulations, Non-ministerial Government Institution Regulations, Non-structural Institution Regulations, and Regional Regulations. Judging from the formulation of the regulation, the principle of transparency [16] and efficiency appears guaranteed through this pathway. After the application files successfully registered, 7 (seven) days later 
[17] the mediation can be held in an encounter between the applicant and the related party for maximum 3 (three) times for each request [18] by the Examining Council consisted of 5 (five) persons, namely three persons from the Ministry and two from the academic elements. [19] As written in the provisions of Article 14 of Permenkumham No. 2/2019, the results of mediation can be in the form of an agreement between the parties and recommendations prepared by the Minister of Law and Human Rights per the reports. [20]

This policy (beleid) has drawn criticism from legal scholars. The substance of Permenkumham is considered inconsistent with the authority of the Ministry of Law and Human Rights and exceeds the Supreme Court's judicial review authority. In accordance with the concept of Pancasila's rule of law, all legislations ruled, either as the derivation of UUD NRI 1945, implementation of the law, or the practice of duties and functions stipulated in the law, the rules must be vertically comformed with constitution and laws. Therefore, normative control needs to be applied through judicial reviews by Constitutional Court and Supreme Court. [21] As written in Article 24 A UUD 1945 jo. Article 20 paragraph (2) letter (b) of Law No. 48 of 2009 concerning Judicial Power (Judicial Power Law) jo. Article 9 paragraph (2) Law No. 12 of 2011 concerning Establishment of Legislation, the Supreme Court has the authorities to:

I. adjudicate the appeal judgment verdicted at the highest level of court in all jurisdictions under the Supreme Court, unless the law governotherwise;

II. examine the laws and regulations under the law against the law; and

III. other authorities granted by law.

The object of Permenkumham is the Supreme Court's authority of judicial review. Furthermore, based on Article 20 paragraph (3) of Law 4/2004, regarding the authority to examine statutory regulations under the law on the law, it is affirmed that the statement of inapplicable legislation as the results of the review can be ruled both in the examination of the appeal or by a direct application to MA. Article 31 paragraph (2) Law No. 5 of 2004 concerning Amendment to Law No. 14 of 1985 concerning the Supreme Court (MA Law) jo. Article 6 Supreme Court Regulation (PERMA) No. 1 of 2011 concerning Judicial Review Right states that after the review, the Supreme Court has the authority to declare illegitimate legislation under the law for reasons contrary to the higher laws or the establishment does not meet the applicable provisions. In its judgment, Supreme Court can declare that the laws and regulations being filed for objection are invalid and inapplicable for the public, and order the relevant agencies and their revocation. [22] In the case of unreasonable application, the Supreme Court denied it. [23] Considering the original intent of establishment of the Supreme Court's power to conduct judicial review in Constitution of the Republic of Indonesia of 1945, this authority is regulated concretely to encourage checks and balances between branches of government. The control system between state institutions is realized effectively when the legislative and executive institutions issue regulations whereas judicial institutions are authorized to examine the relevant legal products that are considered by the public violate their rights, [24] by ratifying or canceling in accordance with the theory of balance of state institutions where institutions monitor the performance of other state institutions. [25] In addition, the judiciary is a free and independent institution. It is through its exercise of judicial review that the judicial system is protected from undue external pressures. [26] Supporting Friedman's opinion, Mahfud MD revealed that an act is a product of political hegemony or domination and compromise among its forming organs, thus the judicial institution is in strategic position to enhance the legislations by constitutional review. Nevertheless, the Directorate General of Legislation in Ministry of Law and Human Rights that is under and responsible for the President. [27] Therefore, the Ministry is not an institution free from competing political wills. Moreover, the Ministry is not a main institution comparable to the Supreme Court. Hence, these two institutions cannot be juxtaposed to develop similar authority. In addition, the object of mediation consists of regulations issued by executive branch, consisted of the Minister, Non-Ministerial Government Institutions, Non-structural Institutions, and Regional Governments, which likely cause conflicts of interest.

A view by Bradley Thayer questioned if the legislature had ratified a bill that was unconstitutional and then had to decide its unconstitutionality. [28] The rationality of review by the legislature here is questionable. In fact, legal review is never the duty, authority, or function of the Ministry of Law and Human Rights following the provisions of Article 11 jo. Article 3 Presidential Regulation No. 44 of 2015 concerning the Ministry of Law and Human Rights (Perpres 44/2015). Meanwhile, written in the consideration of Permenkumham No. $2 / 2019$, norm disputes resolution is implied within the duties and functions of Dirjen PP, namely the formulation and implementation of policies in the fields of construction, harmonization, enactment and publication, legislation litigation, facilitation of drafting legislation in the regions on requests, and mentoring the legislatures. [229] In practice, efforts to harmonize the laws and regulations implemented in each law bureau or the Directorate of Harmonization of Laws and Regulations in the Dirjen PP, as well as the settlement of norm disputes by the Litigation Directorate against non-harmonized legislation. Therefore, mediation on disharmony of regulations only creates an unnecessary burden. [30] No eligible legal standing of the norm disputes mediation by Ministry is the main concern.

In contrary of all the facts above, the effectiveness of the mediation results has been proven in the promulgation of ESDM Minister Decree No. 23 K / MEM / 2019 concerning Amendment to Decree of the Minister of Energy and Mineral Resources Number 1802 K / 30 / MEM / 2018 concerning Wilayah Izin Usaha Pertambangan dan Wilayah Izin Usaha Pertambangan Khusus Periode 2018. This call cancelled and declared invalid the fourth attachment in the ministerial decree which lists the Silo Block area as a gold mining area that is postulated to contradict with Government Regulation No. 23 of 2010 concerning Business Activities. As stated in the consideration of the Minister of Energy and Mineral Resources No. 23/2019, this revocation is a concretization of the results of the dispute resolution of legislation through non-litigation registered in number $31 / \mathrm{NL} / 2018$ within 
Kemenkumham pleaded by the Silo Regency Government. [31] The essence of mediation fulfilled effectively in this case despite the critiques towards this recent non-litigation mechanism However, the mediation agreement was inseparable from ignorance. This is proven by an agreement between the Indonesian White Cigarette Manufacturers Association (Gaprindo) and the local government on September 20, 2018 regarding the prohibition on displaying cigarette products in retail stores ruled in Bogor City Regional Regulation (Perda) Number 12/2009 concerning Non-Smoking Areas and Bogor Mayor Regulations (Perwali) Number 3/2014 as the derivation of the relevant Perda contradicts with Government Regulation Number 109 of 2012 on Secured Materials Containing Addictive Substances in the Form of Tobacco Products for Health. In the agreement, the parties agreed on five points, including the relevant Regional Regulation to be adjusted to PP No. 109/2012 and Perwali will be revoked. Despite the recall of Regional Regulation No. 12/2009, the Regional Regulation Number 10/2018 concerning Non-Smoking Regions as the replacement governs the same substance. [32]

Further comprehensive research needs to be conducted in the present and future cases regarding the practice of the mediation since this regulations review mechanism has just applied in a few months.

\section{CONCLUSION}

Review of norm disputes through mediation by the Directorate General of Legislation of the Ministry of Law and Human Rights regulated in Permenkumham Number 2 of 2019 raises inconsistencies with Article 24A of the 1945 Constitution which mandates that judicial review of legislation under the Act be the authority of the Supreme Court. Moreover, norm dispute resolution overpowers the duty, authority, or function of the Directorate General of Legislation along with the Ministry of Law and Human Rights as ruled in the provisions of Article 11 jo. Article 3 Presidential Regulation No. 44 of 2015 concerning the Ministry of Law and Human Rights. Therefore, synchronization between the Permenkumham concerned with the regulations above is an urgency to establish. Ministry of Law and Human Rights is demanded to formulate supervision body for the execution of the mediation agreement in order to optimize the effectiveness of this alternative norm dispute resolution.

\section{REFERENCES}

[1] Moh. Hasyim, "Pengawasan Kekuasaan Eksekutif dalam Negara Hukum Pancasila", JHIusQuiaIustum No. 6 Vol. 3 Tahun 1996, Fakultas Hukum Universitas Islam Indonesia, p. 59.

[2] Azhari, Negara Hukum Indonesia, Analisis Yuridis Normaif tentang Unsur-unsurnya, (Jakarta: UIPress, 1995), p. 116-118.

[3] Moh. Hasyim, Op. Cit., p. 113.
[4] Hans Kelsen, Pure Theory of Law, (Berkeley, Los Angeles, London: University of California Press, 1978), hal. xiii - xiv.

[5] Zainal Arifin Hosein, "Pokok-Pokok Pikiran tentang Penyelesaian Disharmoni Peraturan Perundangundangan melalui Mediasi”. Seminar by BEM FH UNTAR (Kamis, 9 Mei 2019).

[6] Maria Farida Indrati, Ilmu Perundang-undangan, Jenis, Fungsi, dan Materi Muatan, Yogyakarta: Kanisius, 2007, p. 41.

[7] Jimly Ashiddiqie, Menuju Negara Hukum yang Demokratis, (Jakarta: PT Bhuana Ilmu Populer Kelompok Gramedia, 2009), p. 304.

[8] Ibid.

[9] Article 24 paragraph (2) UUD 1945 jo. Article 47 Law Number 5 Year 1986 concerning State Administration Court (PTUN Act).

[10] Taufiqurrohman Syahuri, Hukum Konstitusi, (Jakarta: Ghalia Indonesia, 2004), p. 49

[11] Maria Farida I., Ilmu Perundang-undangan, Jenis, Fungsi, dan Materi Muatan, (Yogyakarta: Kanisius, 2007), p. 18.

[12] Yuliandri, Azas-Azas Pembentukan Peraturan Perundang-undangan yang Baik, Gagasan Pembentukan Undang-undang Berkelanjutan, (Jakarta: RajaGrafindo Persada, 2010), p. 22-23. Ibid.

[14] Zainal Arifin Hoesein, Judicial Review di Mahkamah Agung, Tiga Decade Pengujian Peraturan Perundang-undangan, (Jakarta: Rajagrafindo Persada, 2009), p.57-58.

[15] Article 3 jo. Article 5 Permenkumham No. $2 / 2019$.

[16] Article 12 Permenkumham No. 2/2019.

[17] After the application has been registered, a copy of the application files shall be submitted to the party relating to the dispute no later than 7 (seven) working days, in accordance with Article 8 of Permenkumham 2/2019. Alongside, the Director General sets out the Examining Board and the Chairperson of the Assembly to immediately determine the date of mediation no later than 7 (seven) working days after the application is registered, as referred to in the provisions of Article 10 paragraph (1) Permenkumham 2/2019. 
[18] Article 13 ayat (4) Permenkumham No. 2/2019.

[19] Pasal 9 ayat (2) Permenkumham No. 2/2019.

[20] Pasal 17 ayat (1) Permenkumham No. 2/2019.

[21] Zainal Arifin Hoesein, Loc. Cit. (dari 20)

[22] Article 6 paragraph (2) PERMA Number 1/2011.

[23] Article 6 paragraph (3) PERMA 1/2011.

[24] Tim Penyusun, Naskah Komprehensif Perubahan Undang-Undang Dasar Negara Republik Indonesia Tahun 1945: Latar Belakang, Proses, dan Hasil Pembahasan 1999-2002 Buku VI Kekuasaan Kehakiman Edisi Revisi, Jakarta: Sekretariat Jendral dan Kepaniteraan Mahkamah Konstitusi, 2010.

[25] Michel Allen and Brian Thoompson, Cases and Materials on Constitutional and Administrative Law, United Kingdom: Oxford University Press, 2002, p.568.

[26] Lawrence M. Friedman and Stewart Macaulay (ed.), Law and Behavioral Sciences, The Bobbs- Merrill Company, Inc. New York, USA, 1969, p. 834.

[27] Article 1 paragraph (1) jo. Article 139 paragraph (1) Permenkumham No. 29 Tahun 2015.

[28] Saldi Isra and Feri Amsari, "Perubahan Konstitusi melalui Tafsir Hukum”, bphn.go.id, p. 6.

[29] Article 139 Permenkumham No. 29/2015 jo. Article 141 Permenkumham No. 24/2018.

[30] Wicipto Setiadi, "Tata Kelola Regulasi yang Baik”, Seminar Quo Vadis Tata Kelola Regulasi Indonesia? by Faculty of Law Universitas Indonesia, 1 November 2018.

[31] Times Indonesia, “Tuntas, Kepmen ESDM tentang Pembatalan Blok Silo Terbit", timesindonesia.co.id, 7 Februari 2019.

[32] Fitriani A. Sjarif, Menggapai Mimpi

Harmonisasi Regulasi, Jakarta: SINDOnews, 2019 